\title{
Interorganizational Mobility within the U.S. Federal Government: Examining the Effect of Individual and Organizational Factors
}

\author{
Jan Wynen 1, Sophie Op de Beeck and Annie Hondeghem \\ KU Leuven, Faculty of Social Sciences, Public Management Institute
}

\begin{abstract}
Interorganizational mobility can make a positive contribution both organizationally and government-wide. Using data from the U.S. Federal Employee Viewpoint Survey, this article seeks to provide a better empirical understanding of the determinants of interorganizational mobility within the U.S. federal government. A specific analytical framework is used since the intention to take another job within the federal government is nested in the intention to leave the current organization. The results highlight that gender, minority status, length of service and promotion are determinants of interorganizational mobility within the U.S. federal government.
\end{abstract}

Keywords: interorganizational mobility, turnover intention, government, bivariate probit model with sample selection 


\section{Introduction}

Mobility across organizations has recently gained ground. As an alternative to lifelong employment within one organization, the notion of the boundaryless career, with its inherent emphasis on cross-employer movements, has found its way into the research field (Sullivan \& Arthur, 2006; Valcour \& Tolbert, 2003). In addition, the belief that the transfer of human capital from one organization to another potentially increases organizational performance has been an important trigger for interorganizational mobility in practice (Somaya et al., 2008).

Also in the public sector, mobility, if well-managed, enables organizations to fulfill crossagency missions. Some interorganizational mobility can be intentionally managed by HRM, be it for the purpose of building competencies in new agencies or supplementing competencies in others, or in managing downsizing or through transfers. Also, the upcoming shortage arising from retirement will require HRM to retain scarce talents (Hatum, 2010), even if this means organizing mobility across agencies. Individual agencies can expand their competency pool, fill vacancies and infuse new thinking into the organization. Mobility will not only benefit organizations, but can also be initiated by individual employees who see some form of advantage. Whether it helps them improve their skills, advance in their careers (e.g. promotions) or get exposure to a broader network, employees may perceive an interorganizational transfer more attractive than resigning from the public service entirely. Since the environment in which the government operates is becoming increasingly complex and multidimensional, mobility is a key condition to improve government performance (McKinsey, 2012). Numerous governmental agencies must share information and resources, be aware of each other's needs and constraints, and work together for the common good. Although there are some mechanisms in place to promote such collaboration (e.g. the 'fusion centers'2 created by the Department of Homeland Security and the Department of Justice), mobility can meaningfully enhance mutual understanding of cross-agency needs and facilitate 
the exchange of interdisciplinary expertise (McKinsey, 2012). When excessive, however, interorganizational mobility may have negative implications. Mostly, these are related to the negative consequences of employee turnover, such as the loss of performance and expertise (cf. infra; e.g. Lambert \& Hogan, 2009).

In the context of this study, it should be noted that the concept of employee mobility includes several forms of movement. Our focus, however, lies at interorganizational movements within the U.S. federal government, i.e. employees who transfer from one agency or department to another (Scism, 1974). This article seeks to provide a better empirical understanding of the determinants of interorganizational mobility within the U.S. federal government.

The mechanism underlying interorganizational mobility entails two main steps: an employee's intention to leave his/her current organization and to again take on a job in the federal government afterwards. In line with Moynihan and Pandey (2007) inter-organizational ties influence the availability of information about the number and nature of jobs in other agencies. Given the nature of federal agencies (e.g. common procedures, often common locales, inter-organization cooperation), these ties are likely to be quite strong, more so than between firms in the private sector. Consequently, in the public sector, many decisions are joint in nature, and the decision to leave the current agency is contingent on the opportunities available in other agencies. We will make use of turnover literature to predict interorganizational mobility. Analyzing mobility from the perspective of turnover is not uncommon in literature as both issues are strongly related (e.g. Sousa-Poza \& Henneberger, 2004). Turnover is normally described in terms of the probability of employees leaving their organization. Interorganizational mobility within the U.S. federal government however not only implies people leaving their current organization (turnover), but also requires them to move to another organization within the federal government as a whole. Although turnover in 
itself is mostly considered a negative result for the organization, implying costs related to the loss of the performance and expertise of the employee, recruitment costs, and resources invested in training (Grissom et al., 2012; Kellough \& Osuna, 1995; Lambert \& Hogan, 2009), interorganizational mobility still capitalizes upon some of these expenses by retaining talented employees within the broader setting of the U.S. federal government. It is therefore crucial to gain a better understanding of employees' motivations behind their decision to move between organizations. As such, organizations will be more able to control or adjust for these factors.

As far as the methodological perspective is concerned, we have to model this dual intention underlying interorganizational mobility within the federal government into a single equation framework. Since the intention to again take a job in the U.S. federal government is nested in the intention to leave the organization, the two binary decisions need to be studied jointly using a bivariate probit framework. More specifically, we have to consider the possibility that the disturbances of the equation about the intention to take another job in the federal government are correlated with those in the equation estimating intention to leave. Consequently, we assume the existence of unobservable characteristics that affect both intentions under study. In this paper, we therefore examine the two intentions jointly by estimating a bivariate probit model using a sample of the 2011 Federal Employee Viewpoint Survey.

In addition, the bivariate probit model is particularly interesting since it allows us to account for the issue of sample selectivity in the equation estimating intention to take another job at the U.S. federal government. The sample used in estimating this equation is not randomly selected, but depends on the intention to leave the current organization. This selectivity calls for a further refinement of the bivariate probit model (see 5. Estimation Strategy). 
The remainder of this paper is organized as follows: section 2 describes the data, while the theoretical model is developed in section 3 and 4, in which some descriptives as well as results from previous literature are discussed. The methodological features of the bivariate probit model with sample selection are discussed in section 5. Main findings are reported in section 6 , which is followed by some concluding remarks.

\section{Data}

Our analyses make use of the 2011 wave of the Federal Employee Viewpoint Survey. This survey is a tool that measures employees' perceptions of whether, and to what extent, conditions that characterize successful organizations are present in their agencies. The survey is administered by the U.S. Office of Personnel Management and targets full-time, permanent employees of departments and large agencies and the small/independent agencies that accept an invitation to participate in the survey. The wave of 2011 drew responses from 266,000 respondents. In order to ensure representativeness, weighed data is used in our analyses. The weight indicates the number of employees in the survey population the respondent represents. Information about demographic characteristics, such as gender, race, supervisory status, age, and organization size, are used to develop the weights.3

\section{Measuring Interorganizational Mobility within the U.S. Federal Government}

The measure for interorganizational mobility is based on employees' turnover intentions, rather than actual turnover. Turnover intention is "the cognitive process of thinking of quitting, planning on leaving a job, and the desire to leave the job" (Lambert \& Hogan, 2009: 98). In research, the intention to quit is considered to be the immediate precursor and a good forecaster of actual turnover (e.g. Mobley et al., 1979). Moreover, from the employer's point of view, turnover intention may be more important since employees thinking of quitting may 
still be persuaded to stay, for example, by changes in the work environment (Dalessio et al., 1986). In the Federal Employee Viewpoint Survey, employees were asked the following question: "Are you considering leaving your organization within the next year and if so, why?" They were given the following options:

- No,

- Yes, to retire,

- Yes, to take another job within the federal government,

- Yes, to take another job outside the federal government, or

- Yes, other.

Since we are only looking at movements within the active labor market, retirement as an answer category was dropped from our analyses. Retirement also raises very different issues than those connected to employees' turnover intentions (Kellough \& Osuna, 1995) and would therefore give biased results. Based on the remaining categories, two dependents were constructed. First a dummy indicating 'intention to leave' was developed in which the answer category "No" was coded 0 and the categories "Yes, to take another job within the federal government", "Yes, to take another job outside the federal government" and "Yes, other" were coded 1. Furthermore, we constructed a dummy indicating 'intention to take another job within the federal government'. This dummy is set to 0 if respondents answered; "Yes to take another job outside the federal government" or "Yes, other", and is set to 1 if respondent chose the answer category "Yes, to take another job within the federal government". Consequently two binary dependents were constructed:

- Intention to leave the current organization

And if the respondent has this intention:

- Intention to take another job within the federal government 
The fact that no answer category indicating 'Yes, do not know yet' was included in the survey could be perceived as a weakness of our data. However, we didn't have any influence in the development of the questionnaire and assume that in case respondents had no information on their new job, they would not fill in the question; leading to a missing value. Consequently, we believe our data to be representative.

\section{Please include Figure 1 here}

In Figure 1, an overview is given of the mobility of federal employees. The majority has no intention to take another job. However, when employees do have the intention to leave their current organization, we notice that a large majority $( \pm 70 \%)$ wants to keep working within the U.S. federal government. The presented percentages are based on the data used for analysis, while percentages in brackets represent the full dataset.

\section{Explanatory Variables}

This section introduces and describes the variables used in this study and the main rationale underlying their adoption. We first introduce the specific drivers of interorganizational mobility, based on turnover literature, and then depict some descriptive statistics useful in the characterization of our samples.

The factors determining interorganizational mobility can be categorized in several ways. In this article, we distinguish, in line with the study of Moynihan and Landuyt (2008), between individual demographic and personal factors on the one hand, and organizational and work environment factors on the other. However, a comprehensive discussion of all possible determinants of interorganizational mobility lies beyond the scope of this paper. Instead, we will focus on variables that will be incorporated in the subsequent empirical analysis. Based on March and Simon's (1958) assumption that employees choose to stay or leave depending 
on several factors affecting the perceived desirability and ease of movement, we develop several individual and work-related hypotheses of the turnover decision.

\section{- Individual factors}

The individual characteristics, be it demographic or personal factors, included in our study are gender, age, length of service, and minority status.

Gender. Several authors have found literature on gender differences in turnover behavior to be inconclusive (Martin, 1979; Mobley et al., 1979; Moynihan \& Landuyt, 2008; Kellough \& Osuna, 1995). Some studies have found no relation between gender and intention to quit (e.g. Dowding \& John, 2008), while others concluded that women are less likely to move across employers (e.g. Lee \& Whitford, 2007; Sousa-Poza \& Henneberger, 2004). Nevertheless, most studies in this area find evidence of turnover intention to be higher for women (e.g. Valcour \& Tolbert, 2003). There are several explanations underlying the possible gender difference in interorganizational mobility. First of all, there is the traditional hypothesis which states that women are more likely to quit due to family commitments such as child care and the maintenance of the household (Camp, 1994; Lewis, 1991; Moynihan \& Landuyt, 2008). Meanwhile, the increase in women's labor force participation, combined with work-life arrangements (cf. infra) such as family leave policies have made women less likely to leave their organization (Moynihan \& Landuyt, 2008). Finally, Moynihan and Landuyt (2008) make an interesting argument for a distinct relationship between gender and turnover in public sector employment. They state that the public sector is considered to be a more attractive setting for women than the private sector. Moynihan and Landuyt (2008) cite several reasons why females would prefer the public sector and, hence, may be less likely to consider leaving the public sector than males, including the substantial progress in gender representation (Choi, 2009; Llorens et al., 2008), a lower wage penalty than in the private sector (cf. wage gap between men and women; e.g. Gornick \& Jacobs, 1998), and a greater 
potential to find balance between work and family life (Buelens \& Van den Broeck, 2007; Kolberg, 1991). Considering everything, we hypothesize that female employees are less likely to leave their current organization. However, if female employees do decide to leave their organization, they will be more likely to again take a job in the federal government (interorganizational mobility within U.S. federal government).

Age. Age has consistently been found to be negatively related to turnover (e.g. Kellough \& Osuna, 1995; Leggatt, 1979; Lewis, 1991). Younger employees are more likely to consider interorganizational movements as they are less attached to a particular employer, often undecided on a preferred career path, and possibly still unrestricted by family responsibilities and financial obligations which might otherwise limit their intent to leave (Kellough \& Osuna, 1995; Lewis, 1991). Furthermore, the life cycle stability hypothesis suggests that "older and more settled employees with familial obligations are less likely to quit" (Moynihan \& Landuyt, 2008: 122). As people age, they have a clearer idea of what they want to do and have more to lose from changing employers. In addition, they are more likely to have developed firm-specific knowledge and skills with a given employer, become more attached to a particular employer, and may face greater age discrimination in seeking new jobs (Lambert \& Hogan, 2009; Lewis, 1991; Valcour \& Tolbert, 2003). Overall, older employees tend to perceive a lower ease of movement and, hence, have a lower propensity to leave (Leggatt, 1979: 854). Therefore, we predict that age is negatively related to turnover intent. The increase in both (government or agency-specific) knowledge and organizational attachment as people age, leads us to suggest a greater likelihood of an employee staying within the federal government as he/she gets older.

Length of service. Although age and length of service are connected, their role in determining turnover is underpinned by different theoretical explanations (Moynihan \& Landuyt, 2008). Therefore, both are included in our analysis as distinct explaining factors. 
Previous studies consistently suggest that longer serving employees are less likely to move to another organization (Doering \& Rhodes, 1996; Kellough \& Osuna, 1995; Lewis, 1991; Martin, 1979; Moynihan \& Landuyt, 2008; Muchinsky \& Morrow, 1980). The longer an employee stays within an organization, the greater his/her specialization or firm-specific knowledge and the higher the long-term investments, such as pay and seniority, the person will have (March \& Simon, 1958; Lambert \& Hogan, 2009; Moynihan \& Landuyt, 2008). In general, greater tenure will imply a greater commitment to the organization, which makes it more difficult to leave the current position. As a result, we assume an inverse relationship between length of service and turnover intention. Within the scope of this paper, we also make the distinction between the length of service in the current organization and the length of service in the U.S. federal government as a whole. If employees with a long record of service do decide to leave their current organization, their tenure within U.S. federal government might still induce them to stay employed within this broader setting.

Minority status. Minority status has been identified in the literature as an important factor in understanding employee behavior (Weaver, 2012). Public organizations are often considered 'model employers' in equal employment opportunities and diversity management. By adopting equal opportunity and diversity initiatives, they intent to establish a bureaucracy representative of the general population (Boyne et al., 1999; Selden \& Selden, 2001), hence creating a favorable environment for minority groups. We, therefore, hypothesize that members of minority groups will generally be less likely to leave their current organization. If they do intent to leave, we assume that they will most likely again choose to work in the U.S. federal government.

\section{- Organizational factors}

Organizational factors describe the interface between individual employees and organizations (Muchinsky \& Morrow, 1980) and may refer to job characteristics, HRM 
policies or the work environment (Moynihan \& Landuyt, 2008). The variables included in our study cover all three categories: workload, personal accomplishment, pay, awards, promotion, work-life balance, training, co-worker relations, and supervisor support. Overall, personenvironment fit theory (Schneider et al., 2000) suggests that the interaction between employees and their job or organization may explain work behavior. Hence, a misfit between an employee and various organizational elements can lead to turnover intentions (Galletta et al., 2011).

Job characteristics. First of all, different aspects of the job itself may influence the intent to stay in that job. A traditional factor and key predictor in the category of job characteristics is job satisfaction (e.g. Battistelli et al., in press; Lambert \& Hogan, 2009; Mobley et al., 1979; Moynihan \& Landuyt, 2008). However, our study doesn't include job satisfaction as a separate determinant of interorganizational mobility. In fact, job satisfaction is often considered an aggregate of several indicators referring to various aspects of the job, such as attitudes towards pay, promotion, and supervision (Warr et al., 1979). Therefore, this article does contain several factors associated with job satisfaction (e.g. pay, work-life balance, supervisor support; cf. infra), which allow us to examine the relation between job satisfaction and interorganizational mobility in more detail. Overall, a negative relationship between elements of job satisfaction and turnover intention is assumed, often mediated by organizational commitment (Battistelli et al., in press; Lambert \& Hogan, 2009). More specifically, we expect an employee's feeling of personal accomplishment and the perceived workload to influence the intent to leave.

Personal accomplishment. Personal accomplishment can be considered a favorable aspect to the job. As such, employees who feel personally accomplished, i.e. who experience feelings of competence and successful achievement in one's work (Maslach \& Jackson, 1981), will be less likely to move to another organization. 
Workload. Job characteristics associated with burnout are believed to increase the desire to leave the current job (Kim, 2005). Accordingly, a greater workload is suggested to be positively related with turnover (Moynihan \& Landuyt, 2008).

HRM policies. Several HRM policies are assumed to play a role in reducing turnover (Moynihan \& Landuyt, 2008). In our empirical analysis, we test the impact of pay, awards, promotion, work-life balance, and training. As stated above, these factors are associated with job satisfaction, which is generally negatively related to turnover intent.

Pay. Several authors consider employee retention to be positively related to higher pay levels or pay satisfaction (e.g. Cotton \& Tuttle, 1986; Grissom et al., 2012; Lewis, 1991; Weaver, 2012). It is suggested that extrinsic rewards, such as pay, are essential in motivating employees (Smith, 2005). In addition, it is expected that the higher the actual pay, the lower the probability to find another job or employer offering an even higher pay rate (Lewis, 1991; Sousa-Poza \& Henneberger, 2004). Despite rigid pay structures, such as fixed salary scales, this presumption also applies to the public sector (Moynihan \& Landuyt, 2008). Overall, we assume that successively higher amounts of pay will produce successively lower amounts of turnover intention, while it a higher pay should increase employees' intention to take on another job in the federal government.

Promotion. Promotional opportunities within the current organization reduce the likelihood of employees leaving (Doering \& Rhodes, 1996; Grissom et al., 2012). This emphasizes the importance of individual recognition and career improvement (Moynihan \& Landuyt, 2008). In general, we hypothesize that employees perceiving opportunities for merit promotion are expected to be less likely to leave their organization. Again, no assumptions are made regarding the relation between promotion and the intention to take on another job in the federal government, due a lack of literature. 
Work-life balance. Organizational support theory suggests that arrangements facilitating work-life balance can explain variation in turnover behavior. HRM policies supporting the balance between work and family commitments are generally found to be negatively related to various employee outcomes, including turnover (Smith, 2005), either directly or through job satisfaction (Battistelli et al., in press). Considering everything, we predict that the existence of work-life policies reduces turnover intention. However, if employees do decide to leave their organization, they will be more likely to again take a job in the federal government as public organizations are generally believed to hold a greater potential to find a good work-life balance (Moynihan \& Landuyt, 2008). Governments are thus still perceived to be leaders in the area of work-life balance. The U.S. federal government in particular provides an array of (government-wide) family-oriented policies, such as leave programs, flextime, etc. Aspects such as work schedule arrangements and health services programs are left to the agencies to decide upon (OPM, 2013). Even if employees would be dissatisfied with work-life arrangements in their organization or the federal government in general, alternatives in the private sector are likely to even be less adequate.

Training. Employee development programs are found to reduce turnover rates as they may generate employee loyalty (Curry et al., 2005). However, also the reverse relationship is possible. In case of the latter, investments in training may increase employees' employability and thus enhance their ease of movement, possibly resulting in turnover. In other words, employees' improved skills make them more capable of finding a job with another employer (Ito, 2003). Since we consider both lines of reasoning offering a strong argument, we will not posit a particular hypothesis in advance regarding the relationship between an organization's training policies and turnover intention or the intention to leave the federal government.

Work environment. As suggested by climate literature, employees' work-related attitudes are influenced to a great deal by aspects in their work environment (Babin \& Boles, 1996; 
Lambert \& Hogan, 2009). In particular, social exchange theory highlights the importance of relational inducements, such as work-related support from the organization, supervisor, and other employees, in turnover decisions (Maertz et al., 2007; Smith, 2005). The underlying reasoning suggests that employees are less likely to leave when they feel supported by (members of) the organization (Dawley et al., 2008). According to Moos (1981, see Babin \& Boles, 1996: 58), a supportive work environment is characterized by "employee perceptions that co-workers are highly involved in their work and that supervisors support and facilitate employees' work efforts". In this article, we therefore consider two elements of the work environment, the relationship with co-workers and the support received from the supervisor.

Co-worker relations. Co-workers play an important role in supporting employees in their job and should therefore receive more attention (Newman et al., 2011). Although research findings are mixed, it is mostly hypothesized that co-worker relations are negatively correlated with turnover behavior (Cotton \& Tuttle, 1986). Also, the notion of interpersonal conflict (e.g. dissatisfaction with co-workers) is considered an antecedent of turnover (Muchinsky \& Morrow, 1980). Overall, we assume that employees' perception of co-worker cooperation is inversely related to turnover intentions.

Supervisor support. Supervisors play a major role in an employee's turnover decision (Maertz et al., 2007). The literature suggests that employees develop general views concerning the degree to which they perceive that their supervisor offers them support and encouragement and values their contributions towards the organization (Dawley et al., 2008; Griffin et al., 2001; Maertz et al., 2007). "Supervisors also play an important role in structuring the work environment and providing information and feedback to employees." Hereby, they have a significant impact on the employee's affective commitment towards them (Griffin et al., 2001: 538). In addition, employees' perceptions of supervisor support influence their feelings of personal well-being and helps to reduce burnout (Babin \& Boles, 1996; 
Kalliath \& Beck, 2001). As a result, the supervisor-employee relationship is vital in explaining why particular employees remain in their jobs while others leave (Grissom et al., 2012). In this context, research posits a negative relationship between supervisor support and employees' turnover intentions (e.g. Dawley et al., 2008; March \& Simon, 1958; Mobley et al., 1979; Smith, 2005). We adopt this view and hypothesize that greater supervisor support reduces an employee's intention to leave the organization.

Personal accomplishment, workload, co-worker relations and supervisor support are believed to only impact the intent to leave the current organization. These are all factors that are strongly related to the current workplace. Hence, we assume that they do not affect an employee's choice of employment inside or outside the federal government. Therefore, no hypotheses were constructed regarding the relationship between these factors and the intention to again take on a job in the federal government.

\section{Analysis of the regressors}

This section is devoted to a descriptive analysis aimed at investigating the representativeness of the subsamples used in the regression analysis and the possible occurrence of collinearity problems.

Table 1 shows summary statistics for the main variables, a more detailed description of used variables can be found in appendix. The purpose of this Table is to test whether the estimation subsample used in the regressions continues to be representative of the entire sample or is instead biased in one or more variables, because of an unbalanced distribution of missing values. Due to missing data for explanatory variables, we only include observations that have information for all variables included in Equation 1 (intention to leave the current organization), the data used for analysis is limited. Consequently, we compare the averages and standard deviations of the variables introduced in previous sections. First, two samples 
are compared with each other: the entire sample population (Full Sample) and the sample including only the observations that have no missing values for all the variables in the regression estimating intention to leave (Equation 1). Second, we compare intention to take another job at the U.S. federal government across the previous samples and the subsample for the regression assessing the intention to take another job within the U.S. federal government (Equation 2).

\section{Please include Table 1 here}

Overall, the values reported in Table 1 in the Full Sample and Equation 1 columns are very similar. This suggests that missing values were randomly distributed, and that the observations used to estimate the regressions therefore constitute a representative subsample of all the employees that were originally included in the survey. Table 1 , however, indicates that the intention to leave is slightly underrepresented $( \pm 1 \%)$ in Equation 1 . Nevertheless, the descriptive statistics for all the explanatory variables appear not to differ in the two samples, thereby suggesting that the impact of this underrepresentation is negligible. Secondly, the decrease in intention to leave appears to be distributed evenly over the entire population, as there was no 'organizational' bias in the distribution of missing values.

In line with literature (e.g. Moynihan \& Landuyt, 2008) all variables used are based on single items. These kinds of variables can be perceived as a weakness. Yet single items are often not less reliable than multiple response items (e.g. Bergkvist \& Rossiter, 2007; Gardner et al., 1998; Wanous \& Hundy, 2001). Gardner et al. (1998) even point out that single item measures avoid the risk of aggregating multiple measures whose inter-item correlation is due to common method variance.

The linear correlation analysis among regressors is reported in table 2. These correlations are only illustrative of the relationships (that is, the correlations are not used in a 'straightforward' fashion as in standard regression analysis, see later on). Not surprisingly, 
there appears to be a strong correlation between age and years working in the federal government and current organization but also promotion appears to be strongly correlated to other variables. Consequently, we also test for multicollinearity using the variance inflation factor. The mean VIF equals 1.69 whereby, as expected, the highest VIFs exists for number of years working at the federal government (3.07) and number of years working for the current organization (2.82). These values indicate that no collinearity exists between the variables or in other words; that the shared variance of the variables is rather low and their discriminant validity is potentially high.

\section{Please include Table 2 here}

\section{Estimation Strategy}

Since we suspect, in line with literature (e.g. Moynihan \& Pandey, 2007), that the decision to leave the federal government is linked to the decision to stay working for the current organization, we make use of a bivariate model with sample selection. This model allows us to take this linkage into account while controlling for the fact that we estimate the effect of variables on taking another job at the federal government based on a non-random sample. More precisely, we estimate this relationship based on a sample of people who decided to leave their current job. Following Wooldridge (2010), this could lead to biased results. Our dependents thus suggest using a bivariate probit model with sample selection.4 Data on the intention to take another job within the U.S. federal government $\left(\mathrm{y}_{1}\right)$ may only be observed when the other variable 'intention to leave' $\left(\mathrm{y}_{2}\right)$ is equal to one. The model is as follows: 


$$
\begin{aligned}
& y_{i 1}^{*}=\beta_{1} x_{i 1}+\varepsilon_{i 1}, y_{i 1}=1 \text { if } y_{i 1}^{*}>0,0 \text { otherwise } \\
& y_{i 2}^{*}=\beta_{2} x_{i 2}+\varepsilon_{i 2}, y_{i 2}=1 \text { if } y_{i 2}^{*}>0,0 \text { otherwise } \\
&\left(\varepsilon_{1}, \varepsilon_{2}\right) \sim \operatorname{BVN}(0,0,1,1, \rho) \\
&\left(y_{i 1}, y_{i 2}\right) \text { is observed only when } y_{i 2}=1
\end{aligned}
$$

Consequently, there are three types of observations in the sample with specific probabilities, which need to be taken into account when generating the log-likelihood function:

$$
\begin{gathered}
\ln L=\sum_{i=1}^{N}\left\{y_{i 1} y_{i 2} \ln \Phi_{2}\left(\beta_{1} x_{i 1}, \beta_{2} x_{i 2} ; \rho\right)+y_{i 1}\left(1-y_{i 2}\right) \ln \left[\Phi\left(\beta_{1} x_{i 1}\right)-\Phi_{2}\left(\beta_{1} x_{i 1}, \beta_{2} x_{i 2} ; \rho\right)\right]+(1-\right. \\
\left.\left.y_{i 1}\right) \ln \Phi\left(-\beta_{1} x_{i 1}\right)\right\}
\end{gathered}
$$

where $\Phi$ relates to the bivariate normal cumulative distribution. It is important to note that our set-up differs from the two- step Heckit procedure (Heckman 1979). More precisely the use of a full information maximum likelihood approach to maximize equation (2) does not imply the calculation of the inverse Mill's ratio (IMR). However exclusion criteria should still be included. Exclusion criteria are variables which are able to predict leaving the current organization but which have no explanatory power when predicting the decision to stay working within the federal government. These variables have to be included in the selection equation (decision to leave the current organization) but should be excluded from the outcome equation (intention to take another job within the federal government) (see Wooldridge 2010, Chapter 19 for a more detailed discussion). As mentioned in section 4, the variables personal accomplishment, workload, co-worker relations and supervisor are assumed to be important when deciding to leave the current organization but are believed to have no explanatory power when deciding to stay working for the federal government. Although theoretically this makes sense since these variables only offer specific information on the current workplace and are difficult to relate to the federal government in general, statistical tests also support this 
assumption.5 As equation (1) indicates, sample selection arises because the observation of $\mathrm{y}_{1}$ is not random but conditional on the observation of $y_{2}=1$. The appropriateness of the overall approach is indicated by $\rho$. When $\rho=0$, the bivariate model can be estimated using an independent probit model. In other words, $\rho$ represents the extent to which the disturbances in the first and second step are independent. Additionally, the joint significance of the difference of the variables' coefficients estimates with those obtained using a single probit approach is tested. A significant difference indicates that results will differ between the bivariate and single equation approach. Furthermore, marginal effects are calculated since they provide a good approximation to the amount of change in $\mathrm{Y}$ that will be produced by a 1-unit change in $x_{k}$. With binary dependent variables, they give a single number that expresses the effect of a variable on $\mathrm{P}(\mathrm{Y}=1)$.

\section{Results}

\section{Please include Table 3 here}

Table 3 reports the estimates from the bivariate probit model with sample selection.6 Coefficients are included on the left side of the table while marginal effects are calculated on the right side. When investigating the significance of the correlation between the residuals from the equations in the bivariate probit model, we notice that the coefficient of $\rho$ is significantly different from 0 , indicating that a bivariate probit model is the correct approach to deal with these kinds of data. Single equation frameworks might consequently lead to biased results. The fact that the Wald test significantly rejects the similarity between the estimated coefficients and the coefficients obtained using a single probit approach only strengthens this assumption.

When analyzing Table 3, we notice that the variables workload, co-worker relations, supervisor support and personal accomplishment are only included in the selection equation. 
These are the exclusion criteria, and these variables are strongly related to the current workplace of the employee, but are believed to not say anything on the federal government in general. Consequently, these variables are expected to only influence intention to leave the current organization and not the decision to take another job at the federal government. All of these variables are significant. Furthermore, all of them have a negative coefficient, meaning that if the respondent is not satisfied with the workload, their supervisor or have a low feeling of personal accomplishment, then he/she is more strongly inclined to leave the current organization. This intuitively makes sense and is in line with turnover literature.

When examining the other coefficients we notice that sometimes the same effect plays for intention to leave the current organization and the intention to take another job at the federal government. Although some variables, such as age, pay, work- life balance and training influence the decision to leave the current organization, they do not seem to have any impact on the decision to take another job at the federal government.

Pay matters when deciding to leave the current organization, but has no influence on the decision whether or not to stay working in the federal government. The fact that individuals who enjoy better compensation are less likely to quit is supported by public sector research (Cotton \& Tuttle, 1986; Grissom et al., 2012; Lewis, 1991; Weaver, 2012) as pay is considered to motivate employees and employees with a high wage are less likely to find a better paying job elsewhere.

Work-life balance negatively influences the decision to leave the current organization, yet it has no influence on the decision to stay working for the federal government. This is partly in line with Moyniham and Landuyt (2008) since employees who are content with the current work- life balance will be less likely to leave, however and this is surprising, it does not encourage the decision to stay working in the federal government when employees decide to 
leave the current organization. A good work-life balance thus makes employees less likely to leave the current organization, but does not make them stay within the federal government.

In line with Lee and Whitford (2007), Sousa-Poza and Henneberger (2004) and Moynihan and Landuyt (2008) we find that women are less inclined to leave their current job. Furthermore, women are more inclined to stay working at the federal government. Women thus not only have a higher likelihood to keep working for the federal government, they will also be more inclined to stay within their own organization. Several explanations are possible for this observation such as: the substantial progress in gender representation (Choi 2009, Llorens et al. 2008), a lower wage penalty than in the private sector (e.g. Gornick \& Jacobs 1998) and a greater potential to find a good balance between work and family (e.g. Buelens \& Van den Broeck 2007; Kogelberg 1991).

According to theory (Doering \& Rhodes, 1996; Kellough \& Osuna, 1995; Lewis, 1991; Martin, 1979; Moynihan \& Landuyt, 2008; Muchinsky \& Morrow, 1980) age and length of service should have a negative effect on the likelihood of leaving the current organization. We however find mixed results; age and number of years working for the current agency have a negative effect on the likelihood of leaving the current organization, and are thus in line with turnover literature. Number of years working for the federal government, however, has a positive effect on the likelihood of leaving the current organization. A possible explanation could be the fact that in order to grow, employees have to shift across organizations. The higher the level of seniority within the U.S. federal government, the more interesting it is for a person to shift across organizations in order to improve skills and get exposure to a broader network. Also, the number of years working for the federal government may have contributed to an employee's networks, enabling interorganizational movements to meet personal objectives. The fact that number of years working for the federal government has a positive significant effect on the intention to take another job within the federal government, and 
people with more seniority are thus more likely to keep working within the federal government, only supports this statement.

Age however, has no effect on the intention to take another job within the federal government. Number of years working within the organization, on the other hand, has a negative effect on the decision to take another job within the federal government. Based on the above, people with more seniority within their organization are less likely to leave, however if they decide to leave, they are thus less likely to take another job within the federal government. These results are unexpected and clearly call for further research. We could speculate, however, that employees who, despite of their many years of service and their investments in the agency, still choose to leave, must have strong negative views of the federal government.

Members of minority groups are less likely to leave the current organization, which is in line with turnover literature (e.g. Doering \& Rhodes, 1996; March \& Simon, 1958). If they do decide to leave they are less likely to again take a job within the federal government. This result is at odds with current literature and suggests that grouping minorities into one single category may disregard distinct patterns across different minority groups (e.g. see Weaver 2012). It is, however, beyond the scope of this article to explain such differences.

When promotions are based on merit, employees are also more likely to stay with the current organization, which is in line with existing research. Yet we notice a strange effect of this variable for the equation estimating intention to take another job at the federal government. If promotions were based on merit in the previous workplace, employees are less likely to take another job at the federal government. A possible explanation is suggested by Moynihan and Landuyt (2008); employees with greater human capital have a greater ability to find a job elsewhere, promotions can be considered an indicator of skills and capacity. 
Consequently, promotions can have a negative effect on the intention to stay working within the U.S. federal government.

Finally, when training needs are assessed, employees are less likely to leave their current organization. However, contrary to literature (e.g. Ito, 2003) training does not make employees more likely to take a job outside the federal government.

\section{Discussion}

The challenges confronting government are more complex than ever. Overcoming them will require seasoned and flexible employees who have achieved experience through multiagency and, in the best cases, multi-sector experience. Action today will yield significant benefits in the future - not least a stronger, more capable U.S. federal government that is better equipped to fulfill its many-faceted mission (McKinsey, 2012). Examining the determinants of interorganizational mobility however poses an interesting empirical puzzle since the equation estimating intention to leave influences the equation estimating the intention to take another job at the government. Using a bivariate probit model we were able to solve this issue.

The results indicate that the variables affecting turnover intention do not always affect intention to take another job within the government or vice versa. In other words, variables that have a significant influence on the decision to stay with the current organization do not always influence the decision to stay working in the federal government, the same holds the other way around. Contrary to literature we included two variables for length of service; number of years working in the current agency and number of years working for the federal government. This distinction proved important as the number of years working for the agency has a negative effect on intention to leave the current organization but has a positive effect on the intention to quit working for the federal government. Number of years working for the 
federal government had just the opposite effect. A possible explanation could be the fact that in order to grow, employees are required to move across organizational boundaries. The higher the level of seniority, the more interesting it is for a person to shift across organizations in order to improve his/her skills and get exposure to a broader network.

Work-life balance proved to have a significant effect on the decision to leave the current organization, yet it does not affect the intention to stay working in the federal government. When training needs are assessed in the current organization, it influences the decision to leave the current organization but does not influence the intention to stay working for the

federal government. A similar effect could be observed for age: older people are less likely to leave the current organization, yet age has no influence on the intention to take another job within the federal government. Furthermore, other variables such as; experience, promotions and being a member of a minority group have a positive effect on the intention to stay working for the current organization but have the opposite effect on the intention to stay working within the federal government. The above results can be interpreted from a government-wide perspective (e.g. the U.S. Office of Personnel Management) or from a more 'parochial' perspective (i.e. individual departments and agencies). Public managers holding this latter perspective are likely to be more ambivalent about employee movement, favoring it if they are on the receiving end but not if they are on the losing end. This might be considered one of the main reasons why interorganizational mobility can be difficult to manage.

\section{Conclusion}

Our results indicate that convincing managers of individual organizations of the government-wide benefits of interorganizational mobility is crucial. The longer employees keep working within one organization; the less they will be inclined to move to another one. Moreover, results showed that if employees have only seniority within the current 
organization but little seniority in the federal government (i.e. have little experience in other organizations) in general, they will, when they decide to leave, be more likely to leave the federal government. Managers of individual agencies and departments should be convinced of the benefits since they are capable to influence the decision to leave the current organization, e.g. by the use of promotions, the creation of a good work-life balance and fulfilling training needs and offering good supervisor support. Since the intention to take another job is linked to the intention to leave the current organization, the collaboration of managers of individual agencies and departments is essential. Although this article focused on the U.S. federal government, we believe it can be extended to other, similar governments, like the American states and/or other countries. There will be cultural and institutional differences, yet we believe the used determinants for staying or leaving the U.S. federal government to be applicable in a broader setting than just the federal government or, geographically, the United States. In our opinion the theories and findings discussed can, consequently, be useful for a wide range of practitioners.

In a further step, it would be interesting to use the available dataset to research the impact of interaction terms on interorganizational mobility. Given the fact that interaction terms are more difficult to interpret in models based on Maximum Likelihood (such as the probit model), this would however lead us too far. Further research studying this in more detail would be a timely and valuable contribution to the body of knowledge regarding this issue.

An important limitation of our data, however, is the fact that these are cross- sectional in nature. For future research it would be interesting to have panel data, allowing to make more accurate predictions and to examine reversed causality. Furthermore, given the nature of today's recruiting environment, it would be interesting to investigate the career paths of those from the private sector who have sought government careers. Currently, our data do not offer 
such information, yet it would help HR units in addressing the recruitment and retention of such employees.

\section{Acknowledgments}

The authors would like to acknowledge Jesse Stroobants of the faculty of Social Sciences at the University of Leuven (KUL) and the participants of the Brownbag seminar (Public Management Institute, University of Leuven (KUL)) for their helpful comments.

\section{Notes}

1 Corresponding author: Jan Wynen, KU Leuven, Faculty of Social Sciences, PublicManagement Institute, Parkstraat 45 bus 3609, 3000 Leuven, Belgium. Email: jan.wynen@soc.kuleuven.be

2 A fusion center is an information sharing center and is designed to promote information sharing at the federal level between agencies such as the Central Intelligence Agency (CIA), Federal Bureau of Investigation (FBI), U.S. Department of Justice, U.S. military, and stateand local-level government.

3 For more information on the survey, see: http://www.fedview.opm.gov/2011/What/

4 These kinds of models are commonly used in economics, more in particular to study innovation within firms. See for instance: Cassiman and Veugelers (2006) and Rouvinen (2010). However selection models are also used in other fields e.g. Wynen (2013).

5 Two regressions predicting leaving the current organization and leaving the Federal government were estimated using the variables: personal accomplishment, workload, coworker relations and supervisor. The variables were able to predict leaving the current organization (McKelvy \& Zavoina's $\mathrm{R}^{2}$ of 0.220 and a McFadden $\mathrm{R}^{2}$ of 0.129 ) while the 
variables failed to predict the probability of leaving the Federal government (McKelvy \& Zavoina's $\mathrm{R}^{2}$ equals 0.004 / McFadden's $\mathrm{R}^{2}=0.002$ ).

6 Since a 'regular' $\mathrm{R}^{2}$ (degree of variance explained) is not available for the used model, we use another measure of goodness of fit, namely the percentage of correctly classified observations. Our models achieve a percentage of 70.31 and 79.94 . For more information on this measure we refer to Cameron and Trivedi (2009). 


\section{References}

Babin, B. \& Boles, J. (1996). The effect of perceived co-worker involvement and supervisor support on service provider role stress, performance, and job satisfaction. Journal of Retailing. 72. 57-75.

Battistelli, A., Portoghese, I., Galletta, M., \& Pohl, S. (in press). Beyond The Tradition: Test of an Integrative Conceptual Model on Nurse Turnover. International Nursing Review. 60. 103-111.

Bergkvist, Lars and John R. Rossiter (2007). The Predictive Validity of Multiple-item Versus Single-item Measures of the Same Constructs. Journal of Marketing Research, 44 (May): 175-184. Lead article.

Boyne, G.A., Jenkins, G. \& Poole, M. (1999). Human resource management in the public and private sectors: An empirical comparison. Public Administration. 77. 407-420.

Buelens, M. \& Van den Broeck, H. (2007). An Analysis of Differences in Work Motivation between Public and Private Sector Organizations. Public Administration Review. 67(1). $65-74$.

Camp, S. (1994). Assessing the effects of organizational commitment and job satisfaction on turnover: An event history approach. The Prison Journal. 74. 279-305.

Cassiman, B., Veugelers, R. (2006), In search of complementarity in innovation strategy: Internal R\&D and external knowledge acquisition. Management science, 52(1), 68-82.

Choi, S. (2009). Diversity in the U.S. Federal Government: Diversity Management and Employee Turnover in Federal Agencies. Journal of Public Administration Research and Theory. 19(3). 603-630. 
Cotton, J.L. \& Tuttle, J.M. (1986). Employee turnover: A meta-analysis and review with implications for research. Academy of Management Review. 11. 55-70.

Curry, D., McCarragher, T. \& Dellmann-Jenkins, M. (2005). Training, transfer, and turnover: Exploring the relationship among transfer of learning factors and staff retention in child welfare. Children and Youth Service Review. 27(8). 931-948.

Dalessio, A., Silverman, W. \& Schuck, J. (1986). Paths to Turnover: A Re-analysis and Review of Existing Data on the Mobley, Horner, and Hollingsworth Turnover Model. Human Relations. 39. 245-263.

Dawley, D.D., Andrews, M.C. \& Bucklew, N.S. (2008). Mentoring, supervisor support, and perceived organizational support: what matters most? Leadership \& Organization Development Journal. 29(3). 235-247.

Doering, M. \& Rhodes, S.R. (1996). Intraorganizational and Interorganizational Job Change: A Discriminant Analysis. Journal of Business and Psychology. 11(2). 151-170.

Dowding, K. \& John, P. (2008). The Three Exit, Three Voice and Loyalty Framework: A Test with Survey Data on Local Services. Political Studies. 56. 288-311.

Galletta, M., Portoghese, I., Penna, M.P., Battistelli, A. \& Saiani, L. (2011). Turnover intention among Italian nurses: The moderating roles of supervisor support and organizational support. Nursing and Health Sciences. 13. 184-191.

Gardner, D. G., Cummings, L. L., Dunham, R. B., \& Pierce, J. L. (1998). Single-item versus multiple-item measurement scales: An empirical comparison. Educational and Psychological Measurement. 58. 898-915.

Gornick, J. C., \& Jacobs, J. A. (1998). Gender, the welfare state, and public employment: A comparative study of seven industrialized countries. American Sociological Review. 63(5). 688-710. 
Greene, W. (2003). Econometric Analysis, fifth ed. Prentice Hall, Englewood Cliffs.

Griffin, M.A., Patterson, M.G. \& West, M.A. (2001). Job satisfaction and teamwork: the role of supervisor support. Journal of Organizational Behavior. 22. 537-550.

Grissom, J.A., Nicholson-Crotty, J. \& Keiser, L. (2012). Does My Boss's Gender Matter? Explaining Job Satisfaction and Employee Turnover in the Public Sector. Journal of Public Administration Research and Theory. 22. 649-673.

Hatum, A. (2010). Next generation Talent management: Talent management to survive turmoil. New York: Palgrave Macmillan.

Ito, J. K. (2003). Career branding and mobility in the civil service: An empirical study. Public Personnel Management. 32(1). 1-21.

Kalliath, T.J. \& Beck, A. (2001). Is the path to burnout and turnover paved by the lack of supervisory support: a structural equations test. New Zealand Journal of Psychology. 30. 72-78.

Kellough, J.E., \& Osuna, W. (1995). Cross-agency comparisons of quit rates in the federal service: Another look at the evidence. Review of Public Personnel Administration. 15(4). $58-68$.

Kim, S. (2005). Factors affecting state government information technology employee turnover intentions. American Review of Public Administration. 35(2). 137-156.

Kolberg, J. E. (1991). The gender dimension of the welfare state. International Journal of Sociology. 21(1). 119-148.

Lambert, E. \& Hogan, N. (2009). The Importance of Job Satisfaction and Organizational Commitment in Shaping Turnover Intent: A Test of a Causal Model. Criminal Justice Review. 34(1). 96-118. 
Lee, S. \& Whitford, A.B. (2007). Exit, Voice, Loyalty, and Pay: Evidence from the Public Workforce. Journal of Public Administration Research and Theory. 18. 647-671.

Leggatt, T. (1979) Managers in Industry: Their Interorganizational Mobility. Human Relations. 32(10). 851-869.

Lewis, G.B. (1991). Turnover and the quiet crisis in the federal civil service. Public Administration Review. 51(2). 145-155.

Lincoln, J. \& Kalleberg, A. (1990). Culture, control and commitment: A study of work organization and work attitudes in the United States and Japan. New York: Cambridge University Press.

Llorens, J.J., Wenger, J.B. \& Kellough, J.E. (2008). Choosing Public Sector Employment: The Impact of Wages on the Representation of Women and Minorities in State Bureaucracies. Journal of Public Administration Research and Theory. 18(3). 397-413.

Maertz, C.P., Griffeth, R.W., Campbell, N.S. \& Allen, D.G. (2007). The effects of perceived organizational support and perceived supervisor support on employee turnover. Journal of Organizational Behavior. 28. 1059-1075.

March, J.G. \& Simon, H.A. (1958). Organizations. New York: Wiley.

Martin, T.N. (1979). A Contextual Model of Employee Turnover Intentions. Academy of Management Journal. 22(2). 313-324.

Maslach, C. \& Jackson, S.E. (1981). The measurement of experienced burnout. Journal of Occupational Behavior. 2. 99-113.

McKinsey (2012). Mission-driven mobility. Strengthening our government through a mobile leadership corps. Washington DC: McKinsey \& Company and Partnership for Public Service. February 2012. 
Mobley, W., Griffeth, R., Hand, H. \& Meglino, B. (1979). Review and conceptual analysis of the employee turnover process. Psychological Bulletin. 86. 493-522.

Moynihan, D.P. \& Landuyt, N. (2008) Explaining Turnover Intention in State Government: Examining the Roles of Gender, Life Cycle, and Loyalty. Review of Public Personnel Administration. 28(2). 120-143.

Muchinsky, P.M., \& Morrow, P.C. (1980). A multidisciplinary model of voluntary employee turnover. Journal of Vocational Behavior. 17. 263-290.

Newman, A., Thanacoody, R. \& Hui, W. (2011). The effects of perceived organizational support, perceived supervisor support and intra-organizational network resources on turnover intentions: A study of Chinese employees in multinational enterprises. Personnel Review. 41(1). 56-72.

O’Driscoll, M.P. \& Randall, D.M. (1999) Perceived Organisational Support, Satisfaction with Rewards, and Employee Job Involvement and Organisational Commitment. Applied Psychology: An International Review. 48(2). 197-209.

Rouvinen, P. (2002) Characteristics of product and process innovators: some evidence from the Finnish innovation survey. Applied Economics Letters. 9:9, 575-580

Ryan, R.M. \& Deci, E.L. (2000). Intrinsic and Extrinsic Motivations: Classic Definitions and New Directions. Contemporary Educational Psychology. 25. 54-67.

Schneider, B., Smith, D.B. \& Goldstein, H.W. (2000). Attraction-selection-attrition: toward a person-environment psychology of organizations. In: Walsh, B.W., Craik, K.H. \& Price, R.H. (Eds.) (2000). Person-Environment Psychology: New Directions and Perspectives (2nd ed.). Mahwah, NJ: Erlbaum. pp. 61-86.

Scism, T.E. (1974). Employee Mobility in the Federal Service: A Description of Some Recent Data. Public Administration Review. 34(3). 247-254. 
Selden, S.C. \& Selden, F. (2001). Rethinking Diversity in Public Organizations for the 21st Century. Moving Toward a Multicultural Model. Administration \& Society. 33(3). 303329.

Smith, B.D. (2005). Job retention in child welfare: Effects of perceived organizational support, supervisor support, and intrinsic job value. Children and Youth Services Review. 27. 153-169.

Somaya, D., Williamson, I.O. \& Lorinkova, N. (2008). Gone but not lost: The different performance impacts of employee mobility between cooperators versus competitors. Academy of Management Journal. 51(5). 936-953.

Sousa-Poza, A. \& Henneberger, F. (2004). Analyzing Job Mobility with Job Turnover Intentions: An International Comparative Study. Journal of Economic Issues. 38(1). 113137.

Sullivan, S.E. \& Arthur, M.B. (2006). The evolution of the boundaryless career concept: Examining physical and psychological mobility. Journal of Vocational Behavior. 69. 1929.

U.S. Office of Personnel Management (2011). Federal Employee Viewpoint Survey. Washington DC: U.S. Office of Personnel Management.

Valcour, P.M. \& Tolbert, P. (2003). Gender, family and career in the era of boundarylessness: determinants and effects of intra- and inter-organizational mobility. International Journal of Human Resource Management. 14(5). 768-787.

Weaver, T.L. (2012). Intent to Exit: What Factors Influence Federal Employees' Decisions to Leave? (dissertation). North Carolina State University. Raleigh, North Carolina. 
Warr, P.B., Cook, J.D. \& Wall, T.D. (1979). Scales for the measurements of some work attitudes and aspects of psychological well-being. Journal of Occupational Psychology. 52. 1063-1070.

Wanous, J.P. \& Hudy, M.J. (2001). Single-Item Reliability: A Replication and Extension. Organizational Research Methods. 4(4): 361-375.

Wooldridge, J.M. (2010). Econometric analysis of cross section and panel data, Cambridge: MIT Press

Work Arrangements and Quality of Work/Life (2005). U.S. Office of Personnel Management. http://www.opm.gov/policy-data-oversight/human-capital-management/referencematerials/talent-management/qualityworklife.pdf

Wynen, J. (2013). Explaining travel distance during same-day visits. Tourism Management. 36. $133-140$. 


\section{Tables and Figures}

\section{Figure 1: Mobility of Federal Employees}

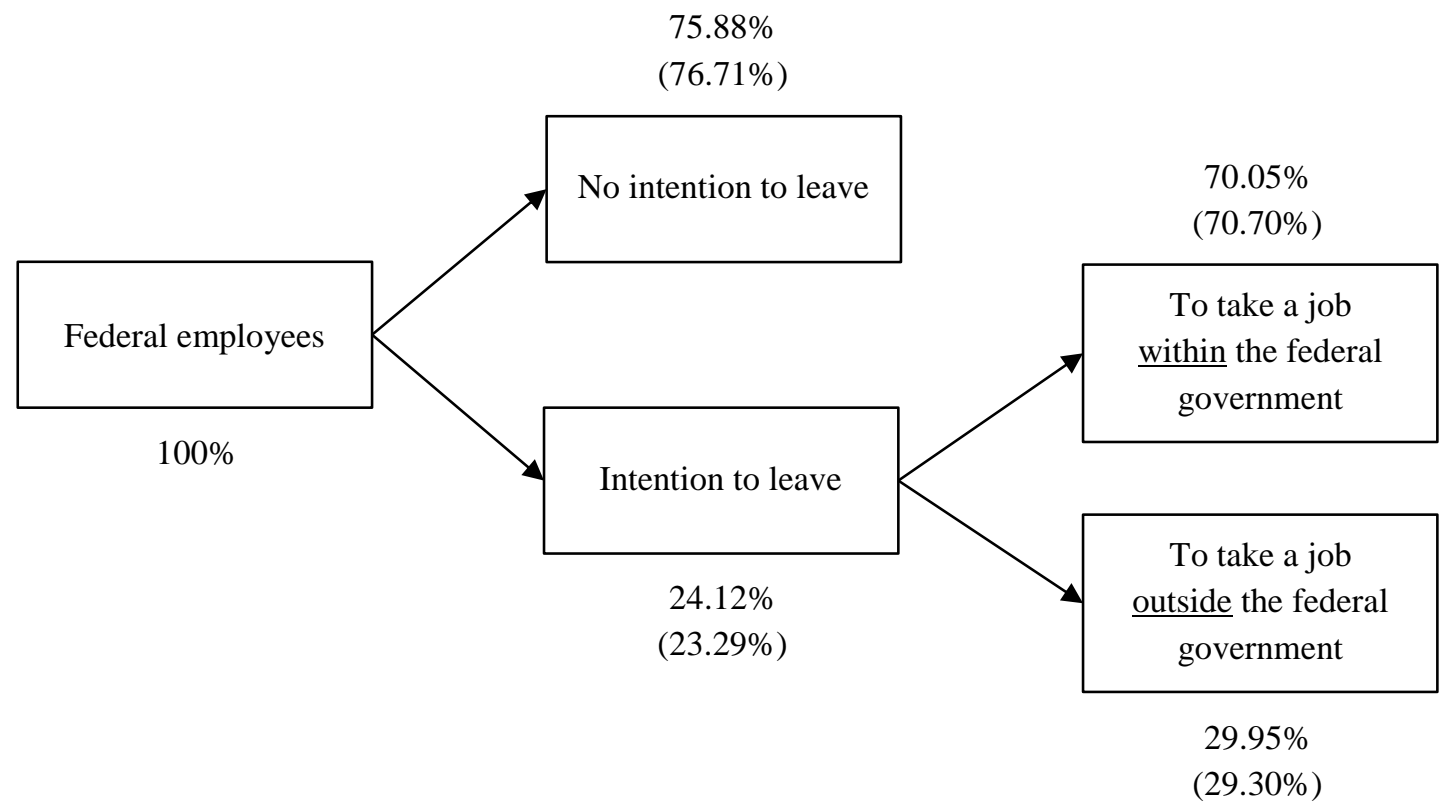




\section{Table 1: Descriptive Statistics for the Independent Variables}

\begin{tabular}{|c|c|c|c|c|c|c|c|c|c|c|c|}
\hline \multirow[b]{3}{*}{ Variables (1) } & \multirow[b]{3}{*}{$\begin{array}{c}\text { Question in } \\
\text { survey* }\end{array}$} & \multirow[b]{3}{*}{ Description } & \multicolumn{3}{|c|}{ Mean } & \multicolumn{3}{|c|}{$S D$} & \multicolumn{3}{|c|}{$N$} \\
\hline & & & $\begin{array}{c}\text { Full } \\
\text { Sample }\end{array}$ & Eq. 1 & Eq. 2 & $\begin{array}{l}\text { Full } \\
\text { Sample }\end{array}$ & Eq. 1 & Eq. 2 & \begin{tabular}{|c|} 
Full \\
Sample
\end{tabular} & Eq. 1 & Eq. 2 \\
\hline & & & (2) & (3) & (4) & & (6) & (7) & & (9) & $(10)$ \\
\hline Intention to leave ( 0 : No; 1 : Yes) & DLEAVING & Dummy & 0.24 & 0.23 & 1 & 0.43 & 0.42 & 0 & 231146 & 179584 & 41831 \\
\hline Intention to take another job at the Federal gov. ( $0:$ No; 1 : Yes) & DLEAVING & Dummy & 0.70 & 0.71 & 0.71 & 0.46 & 0.46 & 0.46 & 55745 & 41831 & 41831 \\
\hline Gender ( 0 : male; 1 : female) & DSEX & Dummy & 0.48 & 0.47 & 0.47 & 0.50 & 0.50 & 0.50 & 231304 & 179584 & 41831 \\
\hline Age & DAGEGRP & Categorical (5 cat.) & 2.28 & 2.29 & 2.06 & 1.05 & 1.04 & 1.02 & 229724 & 179584 & 41831 \\
\hline Minority (0: No; 1 : Yes) & DMINORITY & Dummy & 1.65 & 1.66 & 1.62 & 0.48 & 0.47 & 0.49 & 226399 & 179584 & 41831 \\
\hline Yearfed (How long have you been working for the federal government?) & DFEDTEN & Categorical (6 cat.) & 4.00 & 4.03 & 3.66 & 1.87 & 1.86 & 1.83 & 230362 & 179584 & 41831 \\
\hline Yearagency (How long have you been working for your organisation?) & DAGYTEN & Categorical ( 5 cat.) & 3.19 & 3.22 & 2.76 & 1.48 & 1.47 & 1.40 & 230583 & 179584 & 41831 \\
\hline Salary (Considering everything, how satisfied are you with your job?) & 70 & Categorical ( 5 cat.) & 3.64 & 3.67 & 3.19 & 1.10 & 1.09 & 1.19 & 238103 & 179584 & 41831 \\
\hline Promotion (Promotions in my work unit are based on merit) & 22 & Categorical (5 cat.) & 3.09 & 3.14 & 2.51 & 1.21 & 1.20 & 1.22 & 234909 & 179584 & 41831 \\
\hline Worklife (Senior leaders deomstrate support for Work/ Life programs) & 62 & Categorical (5 cat.) & 3.57 & 3.59 & 3.05 & 1.11 & 1.11 & 1.21 & 222638 & 179584 & 41831 \\
\hline Training ( My training needs are assessed) & 18 & Categorical (5 cat.) & 3.34 & 3.38 & 2.80 & 1.15 & 1.14 & 1.22 & 245006 & 179584 & 41831 \\
\hline Workload (My workload is reasonable) & 10 & Categorical (5 cat.) & 3.36 & 3.38 & 2.95 & 1.13 & 1.13 & 1.23 & 249408 & 179584 & 41831 \\
\hline Cooperation (The people I work with cooperate to get the job done) & 20 & Categorical ( 5 cat.) & 3.89 & 3.92 & 3.54 & 0.95 & 0.93 & 1.08 & 240665 & 179584 & 41831 \\
\hline Supervisor (Overall, how good a job do you feel is being done by your immediate supervisor?) & 52 & Categorical (5 cat.) & 3.95 & 3.98 & 3.40 & 1.11 & 1.10 & 1.27 & 242403 & 179584 & 41831 \\
\hline Personal accomplishment (My work gives me a feeling of personal accomplishment) & 4 & Categorical (5 cat.) & 3.91 & 3.96 & 3.37 & 1.03 & 1.01 & 1.20 & 250104 & 179584 & 41831 \\
\hline
\end{tabular}

*The variable POSTWT has been used as weight 
Table 2 pairwise correlation matrix

\begin{tabular}{|c|c|c|c|c|c|c|c|c|c|c|c|c|c|c|c|c|}
\hline Variables & & (1) & (2) & (3) & (4) & (5) & (6) & (7) & (8) & (9) & (10) & (11) & (12) & (13) & (14) & (15) \\
\hline Leaving the federal government & (1) & 1 & & & & & & & & & & & & & & \\
\hline Leaging the current organizationn & (2) & . & 1 & & & & & & & & & & & & & \\
\hline Gender & (3) & -0.0050 & $0.1222 *$ & 1 & & & & & & & & & & & & \\
\hline Age & (4) & $-0.1209^{*}$ & -0.0059 & $-0.0760^{*}$ & 1 & & & & & & & & & & & \\
\hline Minority & (5) & $-0.0507 *$ & $-0.1642 *$ & $-0.1376^{*}$ & $0.0915^{*}$ & 1 & & & & & & & & & & \\
\hline Yearsfed & (6) & $-0.1011^{*}$ & $0.0257^{*}$ & $0.0759^{*}$ & $0.4754 *$ & $0.0388^{*}$ & 1 & & & & & & & & & \\
\hline Yearsagency & (7) & $-0.1752^{*}$ & $-0.0817^{*}$ & $0.0206^{*}$ & $0.4129 *$ & $0.0736^{*}$ & $0.8018^{*}$ & 1 & & & & & & & & \\
\hline Salary & (8) & $-0.2402^{*}$ & $0.0808^{*}$ & -0.0033 & $0.0132 *$ & $0.0534^{*}$ & $0.0407^{*}$ & $0.0480^{*}$ & 1 & & & & & & & \\
\hline Promotion & (9) & $-0.2823^{*}$ & $-0.0381 *$ & $-0.0359^{*}$ & -0.0064 & $0.0589^{*}$ & -0.0004 & 0.0033 & $0.3821 *$ & 1 & & & & & & \\
\hline Worklife & (10) & $-0.1153^{*}$ & $0.0424 *$ & $0.0345^{*}$ & $0.0621^{*}$ & $-0.0205^{*}$ & $0.0637^{*}$ & $0.0548^{*}$ & $0.1907^{*}$ & $0.2297 *$ & 1 & & & & & \\
\hline Training & (11) & $-0.2757^{*}$ & 0.0109 & -0.0051 & -0.0003 & -0.0081 & $-0.0167^{*}$ & -0.0058 & $0.3015^{*}$ & $0.4942 *$ & $0.2211 *$ & 1 & & & & \\
\hline Workload & (12) & $-0.2071^{*}$ & $0.0322^{*}$ & -0.0053 & -0.0044 & $-0.0556^{*}$ & $-0.0498^{*}$ & $-0.0380^{*}$ & $0.2843 *$ & $0.3040^{*}$ & $0.1638^{*}$ & $0.3737 *$ & 1 & & & \\
\hline Cooperation & (13) & $-0.2174 *$ & -0.0106 & $-0.0340 *$ & $0.0498 *$ & $0.0324 *$ & $0.0299^{*}$ & $0.0448^{*}$ & $0.2580^{*}$ & $0.4331^{*}$ & $0.1704 *$ & $0.3791 *$ & $0.2947 *$ & 1 & & \\
\hline Supervisor & (14) & $-0.2816^{*}$ & $-0.0267^{*}$ & $-0.0226^{*}$ & -0.0057 & $0.0653^{*}$ & $-0.0322^{*}$ & $-0.0130^{*}$ & $0.2928^{*}$ & $0.5017^{*}$ & $0.1730^{*}$ & $0.4720^{*}$ & $0.3001^{*}$ & $0.4247^{*}$ & 1 & \\
\hline Personal accomplishment & (15) & $-0.2999^{*}$ & 0.0129 & 0.0004 & $0.0624^{*}$ & $0.0165^{*}$ & $0.0190 *$ & $0.0445^{*}$ & $0.3075^{*}$ & $0.4451^{*}$ & $0.1792^{*}$ & $0.4417 *$ & $0.3000 *$ & $0.4024 *$ & $0.4363^{*}$ & 1 \\
\hline
\end{tabular}


Table 3: Bivariate Probit Estimates with Sample Selection

\begin{tabular}{|c|c|c|c|c|}
\hline \multirow[b]{2}{*}{ Variables } & \multicolumn{2}{|c|}{ Coefficients } & \multicolumn{2}{|c|}{ Marginal Effects (3) } \\
\hline & $\begin{array}{l}\text { Intention to } \\
\text { take another } \\
\text { job within } \\
\text { the Federal } \\
\text { Government } \\
\text { (y1) }\end{array}$ & $\begin{array}{l}\text { Intention to } \\
\text { leave (y2) }\end{array}$ & $\begin{array}{c}\mathrm{dY} / \mathrm{dX} \\
\mathrm{Y}=\operatorname{Pr}(\mathrm{y} 1=1 / \mathrm{y} 2=1)\end{array}$ & $\begin{array}{c}\mathrm{dY} / \mathrm{dX} \\
\mathrm{Y}=\operatorname{Pr}(\mathrm{y} 2=1)\end{array}$ \\
\hline Gender $($ Female $=1)$ & $\begin{array}{l}0.0537 * \\
(0.0270)\end{array}$ & $\begin{array}{c}-0.0953 * * * \\
(0.0144)\end{array}$ & $\begin{array}{c}0.02118^{*} \\
(0.0107)\end{array}$ & $\begin{array}{c}-0.0271 * * * \\
(0.0041)\end{array}$ \\
\hline Age & $\begin{array}{l}-0.0292 \\
(0.0151)\end{array}$ & $\begin{array}{l}-0.112 * * * \\
(0.00765)\end{array}$ & $\begin{array}{l}-0.0115 \\
(0.0061)\end{array}$ & $\begin{array}{c}-0.0321 * * * \\
(0.00222)\end{array}$ \\
\hline \multicolumn{5}{|l|}{ Length of service } \\
\hline Yearsfed & $\begin{array}{l}0.107 * * * \\
(0.0124)\end{array}$ & $\begin{array}{l}0.0777 * * * \\
(0.00704)\end{array}$ & $\begin{array}{l}0.0422 * * * \\
(0.00504)\end{array}$ & $\begin{array}{c}0.0222 * * * \\
(0.00202)\end{array}$ \\
\hline Yearsagency & $\begin{array}{c}-0.189 * * * \\
(0.0177)\end{array}$ & $\begin{array}{l}-0.231 * * * \\
(0.00872)\end{array}$ & $\begin{array}{c}-0.0747 * * * \\
(0.00755)\end{array}$ & $\begin{array}{c}-0.0662 * * * \\
(0.00249)\end{array}$ \\
\hline Minority status & $\begin{array}{c}-0.248 * * * \\
(0.0275)\end{array}$ & $\begin{array}{c}-0.108 * * * \\
(0.0151)\end{array}$ & $\begin{array}{c}-0.0977 * * * \\
(0.01096)\end{array}$ & $\begin{array}{c}-0.031 * * * \\
(0.00434)\end{array}$ \\
\hline Pay & $\begin{array}{c}0.0121 \\
(0.0133)\end{array}$ & $\begin{array}{l}-0.131 * * * \\
(0.00687)\end{array}$ & $\begin{array}{c}0.00476 \\
(0.00521)\end{array}$ & $\begin{array}{c}0.03756 * * * \\
(0.002)\end{array}$ \\
\hline Promotion & $\begin{array}{c}-0.0669 * * * \\
(0.0147)\end{array}$ & $\begin{array}{l}-0.108 * * * \\
(0.00787)\end{array}$ & $\begin{array}{l}-0.0264 * * * \\
(0.00598)\end{array}$ & $\begin{array}{c}-0.0309 * * * \\
(0.00226)\end{array}$ \\
\hline Work- life balance & $\begin{array}{c}0.0222 \\
(0.0140)\end{array}$ & $\begin{array}{c}-0.0629 * * * \\
(0.00767)\end{array}$ & $\begin{array}{c}0.00877 \\
(0.00546)\end{array}$ & $\begin{array}{l}-0.018 * * * \\
(0.00219)\end{array}$ \\
\hline Training & $\begin{array}{l}-0.0249 \\
(0.0143)\end{array}$ & $\begin{array}{c}-0.0853 * * * \\
(0.00756)\end{array}$ & $\begin{array}{c}-0.0098 \\
(0.00574)\end{array}$ & $\begin{array}{c}-0.0244 * * * \\
(0.00215)\end{array}$ \\
\hline Workload & & $\begin{array}{c}-0.0844 * * * \\
(0.00673)\end{array}$ & & $\begin{array}{c}-0.0242 * * * \\
(0.00191)\end{array}$ \\
\hline Co- worker relations & & $\begin{array}{c}-0.0295 * * * \\
(0.00830)\end{array}$ & & $\begin{array}{c}-0.0084 * * * \\
(0.00238)\end{array}$ \\
\hline Supervisor support & & $\begin{array}{l}-0.111 * * * \\
(0.00755)\end{array}$ & & $\begin{array}{c}-0.0317 * * * \\
(0.00216)\end{array}$ \\
\hline Personal accomplishment & & $\begin{array}{l}-0.171 * * * \\
(0.00782)\end{array}$ & & $\begin{array}{l}-0.049 * * * \\
(0.00224)\end{array}$ \\
\hline Constant & $\begin{array}{l}0.924 * * * \\
(0.0858)\end{array}$ & $\begin{array}{l}2.856 * * * \\
(0.0500)\end{array}$ & & \\
\hline $\mathrm{N}$ & 41831 & 179584 & & \\
\hline$\rho$ & $\begin{array}{l}0.3 \\
(0 .\end{array}$ & $\begin{array}{l}* * * * \\
699)\end{array}$ & & \\
\hline $\begin{array}{l}\% \text { correctly specified } \\
\text { Comparison test (1) }\end{array}$ & $\begin{array}{c}70.31 \\
3.24 * * *\end{array}$ & 79.94 & & \\
\hline Regressors' Wald test (2) & $48.82 * * *$ & & & \\
\hline
\end{tabular}




\section{Appendix}

\section{Detailed description of variables used}

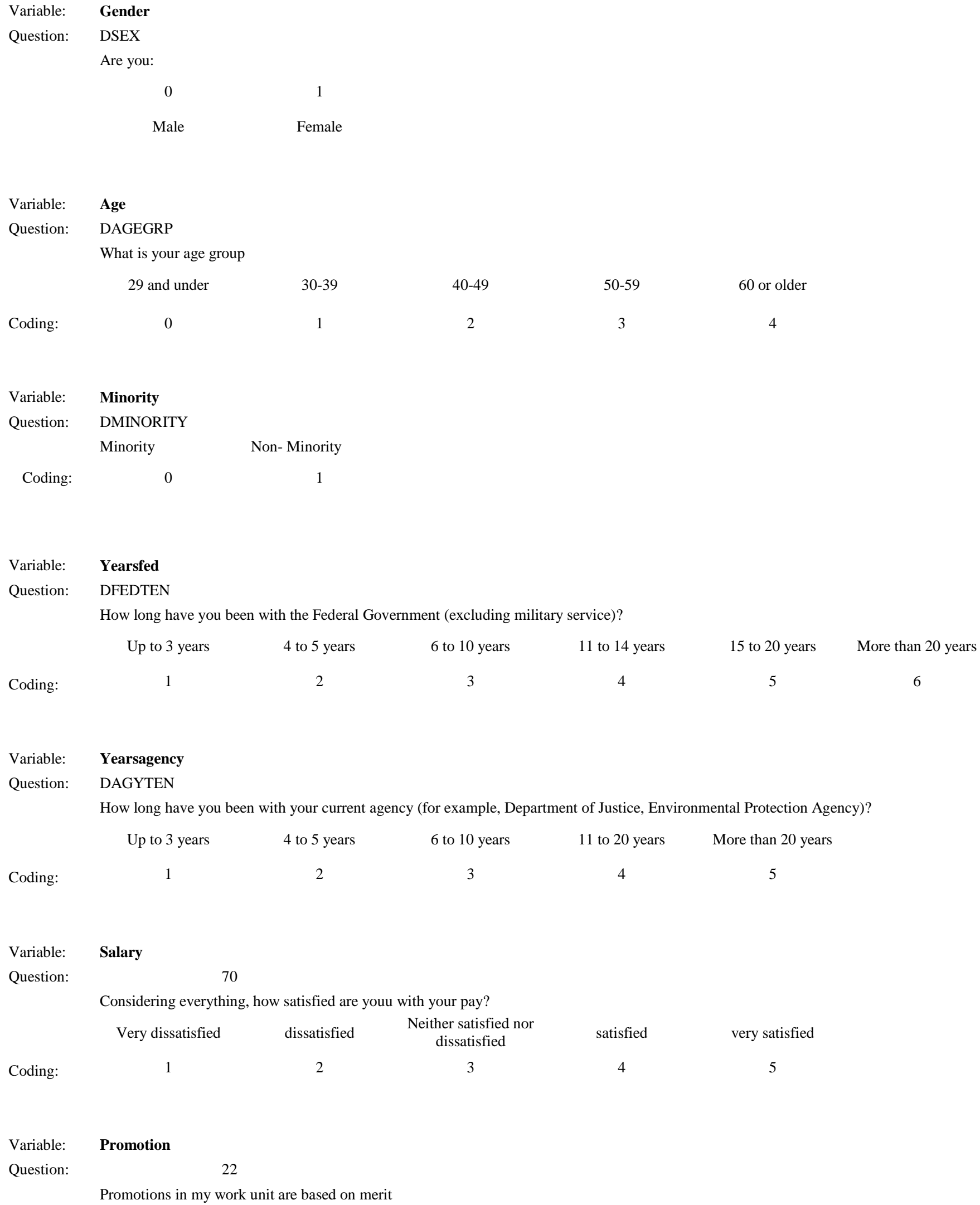

Coding: 0

$\begin{array}{llc}\text { Variable: } & \text { Minority } & \\ \text { Question: } & \text { DMINORITY } & \\ & \text { Minority } & \text { Non- Minority } \\ \text { Coding: } & 0 & 1\end{array}$

$\begin{array}{ll}\text { Variable: } & \text { Yearsfed } \\ \text { Question: } & \text { DFEDTEN }\end{array}$

How long have you been with the Federal Government (excluding military service)?
Up to 3 years
4 to 5 years
6 to 10 years
11 to 14 years
15 to 20 years
More than 20 years

Coding:

Considering everything, how satisfied are youu with your pay?

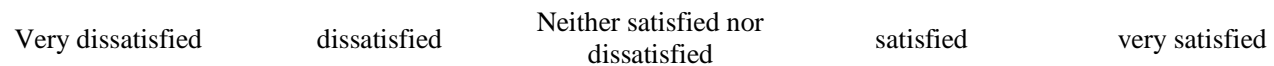

Coding: 1 2

Promotions in my work unit are based on merit 
Coding

Strongly disagree

disagree

2

neither agree nor

disagree

3

agree

4

strongly agree

5

Variable: Worklife

Question:

62

Senior leaders demonstrate support for Work/Life programs

Strongly disagree

disagree

neither agree nor

Coding:

Variable:

Question:

\section{Training}

My training needs are assessed

Strongly disagree

disagree

2

neither agree nor

disagree disagree

agree

4

agree

4

agree

disagree

3
4

agree

4 strongly agree

5

strongly agree

5

strongly agree

Variable:

\section{Cooperation}

The people I work with cooperate to get the job done

$$
\text { Strongly disagree }
$$

disagree

2 neither agree nor disagre

Overall, how good a job do you feel is being done by your immediate supervisor?

$\begin{array}{llll}\text { Very poor } & \text { Poor } & \text { Fair }\end{array}$

2
3
Very Good

5

Variable: Personal accomplishment

Question: 4

My work gives me a feeling of personal accomplishment

Strongly disagree

Coding:

$$
\text { disagree }
$$

2 neither agree nor
disagree

3 agree

4 strongly agree 
Authors Biography PAR-D-12-00379

Jan Wynen is a junior researcher at the public management at the KU Leuven (Belgium). He is currently working on a $\mathrm{PhD}$ project examining the effect of autonomy in the public sector. He holds a master degree in commercial sciences and an advanced master in International Business Economics. His main research interests are econometrics and public sector management.

Sophie Op de Beeck is a junior researcher at the KU Leuven Public Management Institute, Belgium. Her research interests are situated in the area of personnel management in the public sector, more specifically competency management, strategic HRM and the role of line managers in personnel matters. She is currently working on a $\mathrm{PhD}$ project studying the distribution of HRM responsibilities in the public sector and the role of line managers in effective HRM implementation.

Annie Hondeghem is the director of the Public Management Institute of the KU Leuven (Belgium). She is professor of Public Administration. Her research deals with public personnel management, change management and equal opportunities policies. She is a member of the editorial board of PAR. She is the editor (together with prof. James Perry) of Motivation in public management. The call of public service (Oxford University Press, 2008). She is co-convenor of the IIAS study group on Administrative leadership. 